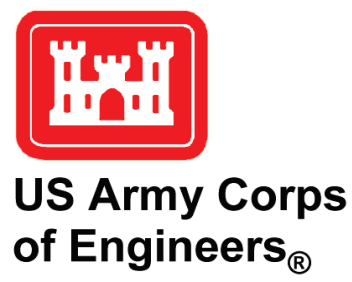

\title{
Use of AIS and AISAP for Analysis of Vessel Wakes in Charleston Harbor: A Case Study
}

by Brandan Scully and Anne McCartney

PURPOSE: This Coastal and Hydraulics Engineering Technical Note (CHETN) describes the uses of Automatic Identification System (AIS) data with the vessel traffic analysis capabilities of the AIS Analysis Package (AISAP) for vessel wake analysis. A case study was performed to demonstrate a cost-effective method for applying AIS data from Charleston Harbor, SC, to estimate relative wake energy contributions from vessel populations projected to call given the alternative scenarios in a deep-draft navigation feasibility study.

INTRODUCTION: The U.S. Army Corps of Engineers (USACE) performs a variety of studies that can benefit from the availability of AIS data that document the movement of vessels interacting with navigation systems. Since 2004, certain vessels are required to broadcast position data every 2 to 10 seconds (s) while underway and every $180 \mathrm{~s}$ while at anchor using AIS. Detailed identifying information (ship name, type, dimensions, etc.) are also transmitted every 6 minutes. The format and availability of AIS data are discussed in detail in ITU (2014).

The AISAP is being developed by the U.S. Army Engineer and Research Development Center (ERDC) to efficiently interpret and extract useful information from AIS data in support of USACE mission requirements. Vessel wake studies, such as those performed by Maynord, (2007) and Maynord et al. (2008), are performed to investigate shoreline impacts resulting from changes to navigation channels and will benefit from AIS derived information.

This case study demonstrates the use of AIS data and desktop methods to make relative comparison between harbor deepening alternatives proposed during the recent Charleston Harbor deepening feasibility study (USACE 2015). The estimated power contributed per unit length of wave crest is used as a proxy to determine whether selected project alternatives are likely to result in vessel-related shoreline erosion beyond that which would arise from the no-action alternative.

CHARLESTON HARBOR CASE STUDY: A reconnaissance study completed in 2010 identified a federal interest in deepening Charleston Harbor beyond its 45 foot (ft) authorized depth, triggering the "Post 45" harbor deepening feasibility study (USACE 2015). Deepening the channel will accommodate larger vessels that are expected to transit the region to meet increased cargo demands following the expansion of the Panama Canal Locks (USACE 2015).

The volume of cargo and vessel fleet composition carrying that cargo through Charleston Harbor was projected in 5-year increments from the year 2022 through 2037 during the Post 45 study. Cargo volume was held constant at each increment for all future project alternatives while the fleet composition was allowed to change with project depth. The future fleet composition was used in this effort to estimate energy contribution from vessel wakes. The study required a 
method to predict changes in vessel wake energy delivered to the shoreline resulting from changes in the vessel fleet composition.

A Post Panamax (PP) Generation III container vessel (beam: $158.3 \mathrm{ft}$; length: 1,200 ft; draft: $50.0 \mathrm{ft}$ ) was recommended as the design vessel for deepening Charleston Harbor. No PP Generation III vessels can access Charleston Harbor; thus, a PP Generation II (beam: $150 \mathrm{ft}$; length: $1200 \mathrm{ft}$; draft: $45 \mathrm{ft}$ ) was used as the pre-deepening design vessel for these analyses; its draft is set equal to the lesser of its design draft or the nominal harbor depth.

The Post 45 vessel classification scheme defined vessel classes by beam (USACE 2015). AIS data collected from 2010 to 2012 and obtained from the U.S. Coast Guard were filtered according the Post 45 scheme with AISAP to obtain vessel summary statistics. The observed vessel draft and length ranges are listed by vessel class in Table 1.

\begin{tabular}{||l|c|c|c||}
\hline \hline \multicolumn{4}{||}{ Table 1. AIS-derived 2010-2012 vessel class dimensions (USACE 2015). } \\
\hline Vessel Class & Beam (ft) & Typical Draft* (ft) & Typical Length (ft) \\
\hline \hline Sub Panamax & $76-99$ & $24-36$ & $480-750$ \\
\hline Panamax & $99-110$ & $29-39$ & $685-950$ \\
\hline Post Panamax Generation I & $110-135$ & $33-45$ & $800-1020$ \\
\hline Post Panamax Generation II & $135-152$ & $35-46$ & $930-1130$ \\
\hline Post Panamax Generation III & $>152$ & - & - \\
\hline
\end{tabular}

*AIS contains a ship's design draft, which is the ship's maximum draft. AIS does not reflect the actual bow and stern sailing drafts.

The overall study footprint of this investigation is based on the current and maximum alternative channel widths evaluated during the Post 45 study. The greater study area was divided into four "areas of interest" as shown in Figure 1. Division was based on ship-speed patterns observed from AIS data in AISAP.

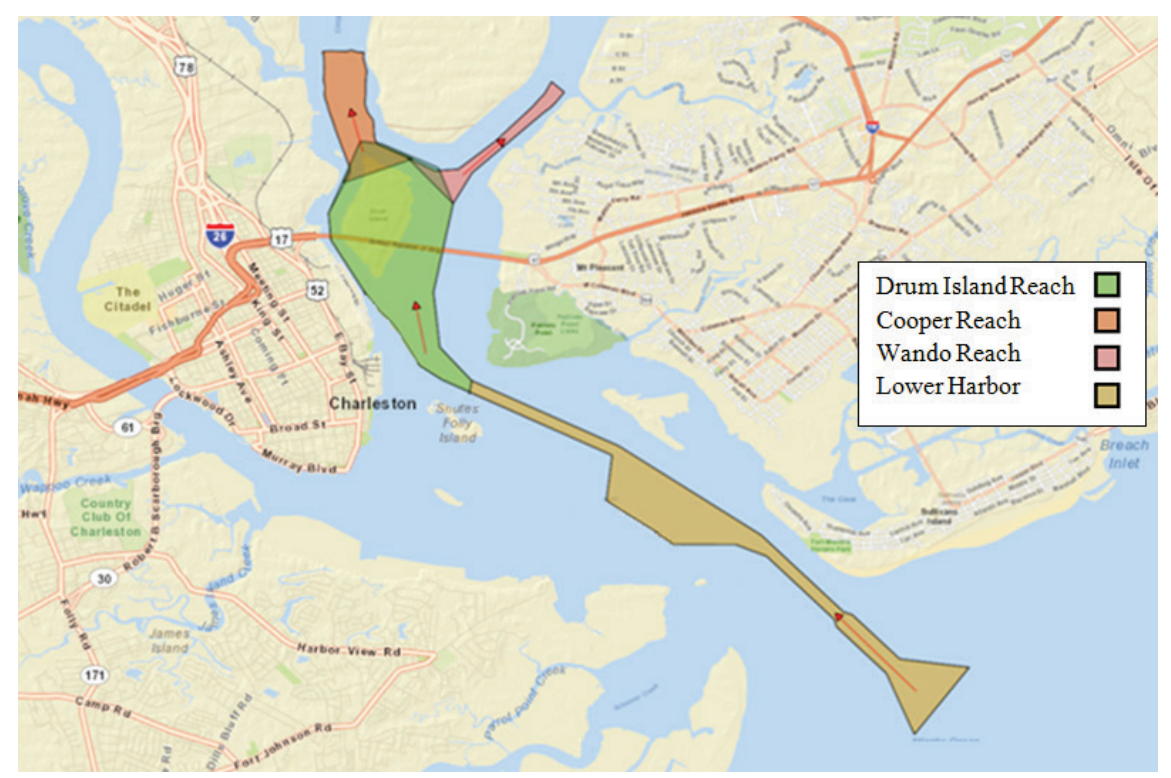

Figure 1. Four areas of interest in the study area. Arrows indicate the inbound transit direction. 
Bank-to-bank bathymetry data collected in 2012 provided baseline channel depths relative to mean lower low water (MLLW), with the shallowest water in the Cooper Reach at the minimum maintained depth of $45 \mathrm{ft}$. Uniform deepening was assumed to occur throughout each AOI in each deepening scenario relative to the actual depth of each reach as determined from crosssection surveys).

ESTIMATING VESSEL WAVE HEIGHT: Estimates of vessel-generated wave heights and power were determined for the vessel traffic in the harbor as presently maintained. Vessel unit wave energy contributions are used as a proxy for total energy delivered to the shoreline from ship traffic.

The empirical model proposed by Kriebel and Seelig (2005) for generalized commercial vessels, consisting of Equations 1-5, was used to estimate vessel-generated wave heights from AIS data:

$$
\begin{aligned}
& \frac{g H}{v^{2}}=\beta\left(F^{*}-0.1\right)^{2}\left(\frac{y}{L}\right)^{-\frac{1}{3}} \\
& \beta=1+8 * \tanh ^{3}\left[0.45\left(\frac{L}{L_{e}}-2\right)\right] \\
& F^{*}=F_{L^{*}} \exp ^{\left(\alpha^{*} d / D\right)} \\
& a=2.5\left(1-C_{B}\right) \\
& F_{L}=v /\left(g^{*} L\right)^{1 / 2}
\end{aligned}
$$

where:

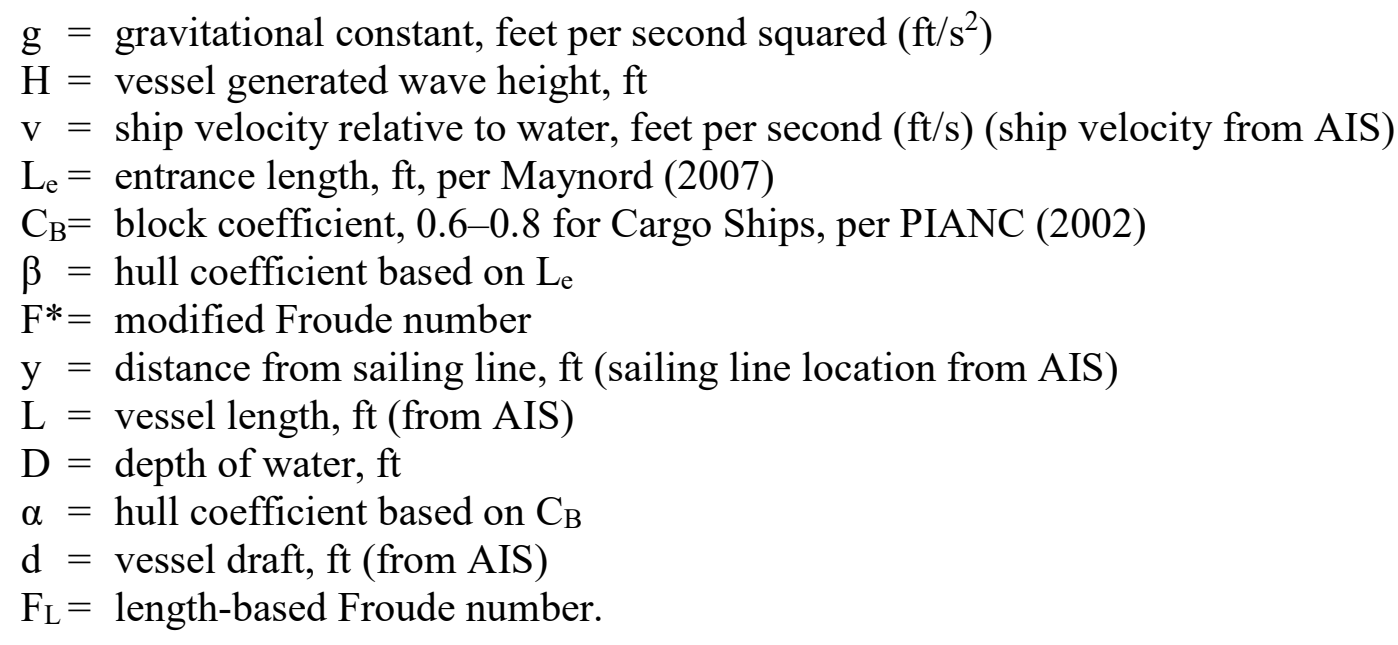


ESTIMATING VESSEL WAKE POWER: The method employed by Maynord et al. (2008) was used to quantify estimates for the total vessel fleet wave action in 2011 and for future projections. Wave heights were converted to total wave power using equations 6-11 (USACE 2008):

$$
\begin{gathered}
\theta=35.27\left(1-\exp ^{(12(F-1))}\right) \\
C=v^{*} \cos (\theta) \\
F=v /\left(g^{*} D\right)^{1 / 2} \\
C^{2}=\left(g^{*} L_{w} / 2^{*} \pi\right)^{*} \tanh \left(2^{*} \pi^{*} D / L_{w}\right) \\
E=\rho^{*} g^{*} H^{2} / 8 \\
P=(C / 2) E
\end{gathered}
$$

where:

$$
\begin{aligned}
& \mathrm{F}=\text { Froude number } \\
& \theta=\text { angle of wave propagation, degrees } \\
& \mathrm{C}=\text { wave celerity (phase velocity), meters per second }(\mathrm{m} / \mathrm{s}) \\
& \mathrm{v}=\text { ship velocity relative to the water, } \mathrm{m} / \mathrm{s}(\mathrm{ship} \text { velocity from AIS) } \\
& \mathrm{E}=\text { wave energy at } \mathrm{J}, \mathrm{J} \text { per square } \mathrm{meter}\left(\mathrm{m}^{2}\right) \\
& \mathrm{P}=\text { wave energy flux, or wave power, through a vertical plane perpendicular to wave } \\
& \quad \text { propagation direction for deep water, } \mathrm{W} / \mathrm{m} \\
& \left.\rho=\text { density of water, } 1025 \text { kilograms per cubic meter }\left(\mathrm{kg} / \mathrm{m}^{3}\right) \text { for salt water }\right) \\
& \mathrm{g}=\text { gravitational constant, meters per second squared }\left(\mathrm{m} / \mathrm{s}^{2}\right) \\
& \mathrm{H}=\text { vessel-generated wave height, } \mathrm{m}^{2} \\
& \mathrm{~L}_{\mathrm{w}}=\text { wavelength, } \mathrm{m} .
\end{aligned}
$$

Equation 9 is the dispersion relationship and was used to estimate wavelength to determine whether the vessel-generated waves are shallow water, transitional, or deep-water waves. The calculated wavelengths ranged from 16.5 to $75.5 \mathrm{ft}$ (5 to $23 \mathrm{~m}$ ) in the $45 \mathrm{ft}(13.7 \mathrm{~m})$ channel depth. The available depth is greater than half the wavelength; vessel-generated waves in this case can be classified as deep water waves, and the use of Equation 11 to estimate power is appropriate.

APPLYING AIS DATA: Vessel length, draft, and velocity parameters used in Equations (1-5) were determined directly from AIS data. AISAP was used to analyze 5,794,032 vessel position reports representing 26,614 transits made by 1,550 unique vessels as listed in Table 2 . Transits observed in 2011 are listed in Table 3. Projected vessel transit counts for the first and last year of this study (2022 and 2037, respectively) are listed in Table 4. 
Table 2. Vessel and transit counts by vessel classes (January 2010-March 2012).

\begin{tabular}{|l|c||c|c|c||}
\hline Vessel Class & Beam (ft) & No. Vessels & No. Transits & No. Reports \\
\hline \hline Sub Panamax & $76-98.9$ & 241 & 1,151 & 433,115 \\
\hline Panamax & $99-109.9$ & 704 & 6,121 & $2,432,210$ \\
\hline PP Generation I & $11-134.5$ & 60 & 891 & 350,361 \\
\hline PP Generation II & $135-152$ & 38 & 276 & 108,161 \\
\hline PP Generation III & $>152$ & - & - & - \\
\hline \hline
\end{tabular}

\begin{tabular}{|c|c|c|c|c|c|}
\hline Vessel Class & Full Channel & Lower Harbor & Drum Island & Cooper & Wando \\
\hline Sub Panamax & 438 & 419 & 412 & 232 & 274 \\
\hline Panamax & 6,290 & 6,150 & 6,198 & 2,442 & 4,321 \\
\hline PP Generation I & 1,503 & 1,458 & 1,499 & 145 & 1,317 \\
\hline PP Generation II & 349 & 331 & 331 & 76 & 317 \\
\hline PP Generation III & 0 & 0 & 0 & 0 & 0 \\
\hline
\end{tabular}

\begin{tabular}{|c|c|c|c|c|c|}
\hline Vessel Class & Year & No Deepening & $3 \mathrm{ft}$ Deepening & $5 \mathrm{ft}$ Deepening & $7 \mathrm{ft}$ Deepening \\
\hline Sub Panamax & 2022 & 700 & 700 & 700 & 700 \\
\hline Panamax & 2022 & 6,630 & 5,898 & 5,873 & 5,860 \\
\hline PP Generation I & 2022 & 5,009 & 5,009 & 5,009 & 5,009 \\
\hline PP Generation II & 2022 & 1,160 & 1,160 & 1,160 & 1,160 \\
\hline PP Generation III & 2022 & 90 & 90 & 90 & 90 \\
\hline Sub Panamax & 2037 & 1,050 & 1,050 & 1,050 & 1,050 \\
\hline Panamax & 2037 & 10,077 & 7,259 & 7,060 & 7,009 \\
\hline PP Generation I & 2037 & 4,188 & 4,050 & 4,018 & 3,996 \\
\hline PP Generation II & 2037 & 3,130 & 3,068 & 3,051 & 3,051 \\
\hline PP Generation III & 2037 & 1,198 & 1,170 & 1,170 & 1,170 \\
\hline
\end{tabular}

Vessel speed and dimension averages, listed in Tables 5 and 6, were needed to determine vesselgenerated wave heights with the Kriebel and Seelig model (2005). Charleston Harbor AIS position data for 2010, 2011, and January-March of 2012 were partitioned by the vessel beam classification established in the Post 45 cargo projection. It was assumed that draft-constrained vessels (all PP generations) will increase draft as the harbor is deepened (Stolker and Verheij 2006). The average vessel dimensions from the AIS data and deepening scenarios led to the development of typical vessel dimensions by class in Table 5 . 


\begin{tabular}{|c|c|c|c|c|c|}
\hline Timeframe & Deepening & Vessel Class & Draft (ft) & Length (ft) & Beam (ft) \\
\hline 2011 and Future* & No Deepening & Sub Panamax & 30.1 & 611.4 & 89.8 \\
\hline 2011 and Future ${ }^{*}$ & No Deepening & Panamax & 34.6 & 816.4 & 104 \\
\hline 2011 and Future* & No Deepening & PP Generation I & 38.9 & 906.7 & 126.2 \\
\hline 2011 and Future* & No Deepening & PP Generation II & 40.5 & $1,030.9$ & 141.3 \\
\hline 2011 and Future* & No Deepening & PP Generation III & 43 & 1200 & 158.3 \\
\hline Future* & $3 \mathrm{ft}$ Deepening & Sub Panamax & 30.1 & 611.4 & 89.8 \\
\hline Future* & $3 \mathrm{ft}$ Deepening & Panamax & 34.6 & 816.4 & 104 \\
\hline Future* & $3 \mathrm{ft}$ Deepening & PP Generation I & 41.9 & 906.7 & 126.2 \\
\hline Future $^{*}$ & $3 \mathrm{ft}$ Deepening & PP Generation II & 43.5 & $1,030.9$ & 141.3 \\
\hline Future* $^{*}$ & $3 \mathrm{ft}$ Deepening & PP Generation III & 46 & 1200 & 158.3 \\
\hline Future $^{*}$ & $5 \mathrm{ft}$ Deepening & Sub Panamax & 30.1 & 611.4 & 89.8 \\
\hline Future* & $5 \mathrm{ft}$ Deepening & Panamax & 34.6 & 816.4 & 104 \\
\hline Future* $^{*}$ & $5 \mathrm{ft}$ Deepening & PP Generation I & 43.9 & 906.7 & 126.2 \\
\hline Future* & $5 \mathrm{ft}$ Deepening & PP Generation II & 45.5 & $1,030.9$ & 141.3 \\
\hline Future* & $5 \mathrm{ft}$ Deepening & PP Generation III & 48 & 1200 & 158.3 \\
\hline Future $^{*}$ & $7 \mathrm{ft}$ Deepening & Sub Panamax & 30.1 & 611.4 & 89.8 \\
\hline Future* & $7 \mathrm{ft}$ Deepening & Panamax & 34.6 & 816.4 & 104 \\
\hline Future* $^{*}$ & $7 \mathrm{ft}$ Deepening & PP Generation I & 45.9 & 906.7 & 126.2 \\
\hline Future $^{*}$ & $7 \mathrm{ft}$ Deepening & PP Generation II & 47.5 & $1,030.9$ & 141.3 \\
\hline Future* & $7 \mathrm{ft}$ Deepening & PP Generation III & 50 & 1200 & 158.3 \\
\hline
\end{tabular}

*Future includes all forecast years including 2022, 2027, 2032, and 2037.

Vessel speed over ground (SOG) was determined by class and reach from AIS data. The average and standard deviation over the full AOI as shown in Table 6. Vessel speeds were highest in the lower reach of the harbor.

\begin{tabular}{|c|c|c|c|c|c|c|}
\hline \multirow[b]{2}{*}{ Vessel Class } & \multicolumn{2}{|l|}{2010} & \multicolumn{2}{|l|}{\begin{tabular}{|r|}
2011 \\
\end{tabular}} & \multicolumn{2}{|l|}{$2012^{*}$} \\
\hline & SOG (knots) & $\sigma$ & SOG (knots) & $\sigma$ & SOG (knots) & $\sigma$ \\
\hline Sub Panamax & 9.8 & 2.3 & 10.1 & 2.1 & 9.4 & 2.6 \\
\hline Panamax & 10.1 & 2 & 10.3 & 1.9 & 10.4 & 2.1 \\
\hline PP Generation I & 9.8 & 1.5 & 10.1 & 1.6 & 10 & 2 \\
\hline PP Generation II & 9.7 & 1.5 & 9.3 & 2 & 9.3 & 2.6 \\
\hline
\end{tabular}

*January through March 2012 were included in this study.

The vessel dimension data in Table 5 and the speed data in Table 6 were used in Equations (1-5) to calculate wave heights for class representative vessels in Charleston Harbor listed in Table 7.

It was necessary to account for the difference between vessel speed through the water and SOG. To conservatively estimate generated wave heights, vessel SOG measured by AIS was adjusted by adding a reach-dependent current speed ranging from 1.38 to $2.1 \mathrm{ft} / \mathrm{s}$ This speed was the average of 50 acoustic Doppler current profiler (ADCP) measurements at least 10 minutes in duration made on 8 May 2012 to observe that month's greatest tidal current. Transits were also assumed to be made at MLLW, which artificially constrained the flow area of the channel. A 
distance from the AIS-estimated sailing line of $975 \mathrm{ft}$ was selected for alternatives comparison, based on a desired $y / L \approx 1$, consistent with the method used by Kriebel and Seeling (2005) in the formulation of Equation (1). Vessel block coefficient was selected according to typical values for cargo ships from the Guidelines for the Design of Fender Systems (PIANC 2002).

\section{Table 7. Wave heights (inches) produced by vessel class at a reference point near the edge of the federal channel $975 \mathrm{ft}$ from sailing line at low tide.}

\begin{tabular}{|c|c|c|c|c|c|c|}
\hline & & \begin{tabular}{|c|} 
Existing \\
Conditions \\
\end{tabular} & $\begin{array}{c}\text { Future }^{*} \\
\text { Conditions } \\
\end{array}$ & $\begin{array}{c}\text { Future }^{*} \\
\text { Conditions }\end{array}$ & \begin{tabular}{|c|c|} 
Future $^{*}$ \\
Conditions $^{2}$
\end{tabular} & $\begin{array}{c}\text { Future }^{*} \\
\text { Conditions }\end{array}$ \\
\hline Deepenir & g Depth & & & & & \\
\hline Vessel Class & AOI & N/A & Deepening & Deepening & Deepening & Deepening \\
\hline Sub Panamax & Full Channel & 1.78 & 1.78 & 1.62 & 1.53 & 1.45 \\
\hline Panamax & Full Channel & 2.51 & 2.51 & 2.24 & 2.09 & 1.95 \\
\hline PP Generation I** & Full Channel & 1.80 & 1.80 & 1.87 & 1.91 & 1.95 \\
\hline PP Generation II** & Full Channel & 1.30 & 1.30 & 1.35 & 1.37 & 1.40 \\
\hline PP Generation III** & Full Channel & - & 1.28 & 1.32 & 1.34 & 1.36 \\
\hline Sub Panamax & Lower Harbor & 4.49 & 4.49 & 4.13 & 3.93 & 3.75 \\
\hline Panamax & Lower Harbor & 7.30 & 7.30 & 6.62 & 6.24 & 5.89 \\
\hline PP Generation I** & Lower Harbor & 5.35 & 5.35 & 5.52 & 5.63 & 5.72 \\
\hline PP Generation II** & Lower Harbor & 4.24 & 4.24 & 4.36 & 4.44 & 4.51 \\
\hline PP Generation III** & Lower Harbor & - & 4.34 & 4.43 & 4.49 & 4.54 \\
\hline Sub Panamax & Drum Island & 0.83 & 0.83 & 0.74 & 0.69 & 0.64 \\
\hline Panamax & Drum Island & 0.69 & 0.69 & 0.58 & 0.53 & 0.48 \\
\hline PP Generation I** & Drum Island & 0.61 & 0.61 & 0.63 & 0.65 & 0.66 \\
\hline PP Generation II** & Drum Island & 0.50 & 0.50 & 0.51 & 0.53 & 0.54 \\
\hline PP Generation III** & Drum Island & - & 0.47 & 0.48 & 0.49 & 0.50 \\
\hline Sub Panamax & Cooper Reach & 0.55 & 0.55 & 0.48 & 0.45 & 0.41 \\
\hline Panamax & Cooper Reach & 0.66 & 0.66 & 0.55 & 0.50 & 0.45 \\
\hline PP Generation I** & Cooper Reach & 0.79 & 0.79 & 0.82 & 0.84 & 0.86 \\
\hline PP Generation II** & Cooper Reach & 0.08 & 0.08 & 0.09 & 0.09 & 0.09 \\
\hline PP Generation III** & Cooper Reach & - & 0.07 & 0.07 & 0.07 & 0.07 \\
\hline Sub Panamax & Wando Reach & 0.56 & 0.56 & 0.49 & 0.46 & 0.42 \\
\hline Panamax & Wando Reach & 0.51 & 0.51 & 0.43 & 0.38 & 0.35 \\
\hline PP Generation I** & Wando Reach & 0.19 & 0.19 & 0.20 & 0.21 & 0.21 \\
\hline PP Generation II** & Wando Reach & 0.12 & 0.12 & 0.13 & 0.13 & 0.14 \\
\hline PP Generation III** & Wando Reach & - & 0.10 & 0.11 & 0.11 & 0.11 \\
\hline
\end{tabular}

*Future includes all forecast years including 2022, 2027, 2032, and 2037.

**Draft varied based on the available minimum depth as indicated in Table 3.

RESULTS: Wave heights were determined to increase up to 0.4 inch (in.) in deepened harbor scenarios. Panamax and smaller vessels produced wave heights that decreased up to 1.4 in. with increasing channel depth. As expected, larger vessels generated larger waves during transit. Vessels with draft-to-depth ratios that decreased following deepening generated smaller waves.

The Post 45 study assumes that a changing fleet of vessels will carry a fixed volume of cargo through the harbor. The number of vessels using the harbor thus increases with projected cargo volume for all alternatives (Tables 3 and 4) based on known port capacities, expected growth, 
and call patterns of vessels predicted to transit the Cooper and Wando Rivers, with the greatest port growth expected to occur along the Cooper River.

Table 8 lists annual wave power estimate of generated per meter of wave crest by the vessel population in each reach for 2011. Actual and projected fleet populations (Table 4) were used to convert wave heights to wave power along the line of interest at $975 \mathrm{ft}$ from the sailing line (Table 9) for the entire fleet per year for each alternative relative to the calculated 2011 baseline (Table 8).

\begin{tabular}{|c|c|}
\hline \multicolumn{2}{|c|}{$\begin{array}{l}\text { Table 8. Total annual power of } 2011 \text { fleet } \\
\text { (Panamax through PP Generation III). Power } \\
\text { values are for relative comparison only and } \\
\text { are not representative of total harbor-wide } \\
\text { power. }\end{array}$} \\
\hline AOI & Power $^{*}(\mathrm{~kW} / \mathrm{m}$ of wave crest) \\
\hline Full channel & 0.0891 \\
\hline Lower harbor & 0.8864 \\
\hline Drum Island & 0.0057 \\
\hline Cooper & 0.0018 \\
\hline Wando & 0.0018 \\
\hline
\end{tabular}

The vessel population forecasts for the Sub Panamax fleet were assumed to increase consistently over time and grow consistently for all deepening scenarios. The impacts of Sub Panamax vessel were considered to be independent from the Panama Canal expansion and harbor deepening, and these were not considered in the comparison of alternatives.

Any scenario with harbor deepening results in a projected reduction in vessel traffic volume that outweighs increases in vessel size compared to the no-action alternative. This results in a lower relative energy contribution in any deepened scenario compared to no-action. The results listed in Table 9 indicate that effects of vessel traffic growth will be lessened by harbor deepening.

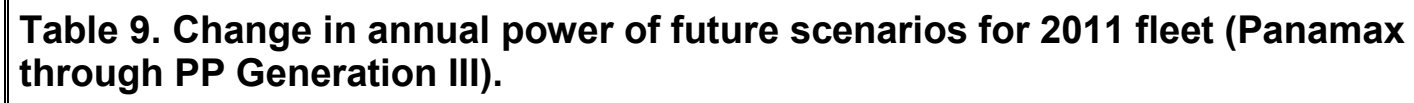

\begin{tabular}{|l|c|c||c|c||c||}
\hline \hline AOI & Year & No Deepening & 3 ft Deepening & 5 ft Deepening & 7 ft Deepening \\
\hline \hline Full channel & 2022 & $32.7 \%$ & $8.4 \%$ & $1.4 \%$ & $-4.1 \%$ \\
\hline Lower harbor & 2022 & $34.3 \%$ & $12.2 \%$ & $6.0 \%$ & $1.1 \%$ \\
\hline Drum Island & 2022 & $47.0 \%$ & $21.1 \%$ & $13.8 \%$ & $8.7 \%$ \\
\hline Cooper & 2022 & $145.8 \%$ & $128.6 \%$ & $122.2 \%$ & $118.4 \%$ \\
\hline Wando & 2022 & $-4.2 \%$ & $-30.3 \%$ & $-42.6 \%$ & $-52.1 \%$ \\
\hline Full channel & 2037 & $86.1 \%$ & $27.5 \%$ & $16.5 \%$ & $9.2 \%$ \\
\hline Lower harbor & 2037 & $90.1 \%$ & $34.5 \%$ & $24.6 \%$ & $18.0 \%$ \\
\hline Drum Island & 2037 & $103.1 \%$ & $43.6 \%$ & $32.3 \%$ & $25.4 \%$ \\
\hline Cooper & 2037 & $156.8 \%$ & $121.4 \%$ & $105.7 \%$ & $94.5 \%$ \\
\hline Wando & 2037 & $42.6 \%$ & $3.2 \%$ & $-15.4 \%$ & $-29.8 \%$ \\
\hline
\end{tabular}

*Vessel traffic is expected to increase greatly in the Cooper River due to expansion of upstream ports. 
DISCUSSION: AIS data allow for significantly more vessel observations than typical studies. Maynord (2007) observed 101 vessel transits over 6 days in 2005 in support of a harbor deepening study at the port of Savannah, GA. This amounts to a study that covers approximately $1 \%$ of the 7,782 vessels transiting the harbor that year (USACE 2005). In comparison, AIS data captured 8,358 transits (lower harbor), or 98\%, of 8,531 transits reported to USACE in 2011 (USACE 2011).

With access to AIS data, the need for field observations can be reduced to specialized cases where AIS data are insufficient. Winkler (2012) discusses data quality concerns and methods being made by the U.S. Coast Guard to encourage improvement of data quality at the source of AIS transmission. In light of known AIS data quality issues, some form of validation of AIS data may be required. User-specified filtering based on vessel characteristics can be applied to exclude problematic data at little cost to accuracy, given the significant available coverage of AIS.

Wave height and power resulting from a vessel transit are influenced by factors including the ratio of vessel depth to vessel draft, hull shape, and the vessel's speed through the water. Total wave energy available to be delivered to the shoreline depends on the number of vessels, length of transit, and the distance to the shoreline. The changes in draft and available depth for larger Post Panamax vessel generations under deepening scenarios compared to existing conditions result in wave heights that are only marginally larger than those of existing traffic, while Panamax and Sub Panamax vessels generated marginally lower wave heights. However, the fixed future cargo projections across all deepening scenarios, and the loading efficiency gained in scenarios where Post Panamax vessels can call on the harbor, result in higher total available energy in the undeepened scenario. This is due to the projected future requirement of relatively more ships in the no-action scenario to carry future projected cargo volumes. Present in all scenarios, but uninvestigated here, are the impacts of non-cargo vessels. It has been suggested ${ }^{1}$ that windgenerated waves and waves generated by smaller displacement vessels (e.g., tugs and service craft) may be more important than container vessels for shoreline impacts in Charleston Harbor.

CONCLUSIONS: AIS technology has reached a point of maturing and widespread adoption that benefits USACE practitioners. Low-cost data are available over a wide spatial and temporal extent, making it a useful resource for planners, designers, and managers. New tools such as AISAP allow for rapid data acquisition, analysis, and visualization of millions of vessel reports. Access to AIS data now enables studies of all budgets and schedules to apply actual vessel traffic data in U.S. coastal regions. The method presented here may provide the basis for an efficient and objective standardized approach to comparative analysis of vessel wake effects of proposed feasibility study alternatives.

The AISAP tool was used with AIS data available in Charleston Harbor to estimate that the increase in wave heights for Post Panamax vessels transiting in deepened navigation channels were less than $0.5 \mathrm{ft}$. However, total energy input to the waterway resulting from vessel traffic increased by the greatest amount in the no-action alternative as compared to any deepening scenario. Available energy increases were due to greater numbers of vessels with lesser cargo

\footnotetext{
${ }^{1}$ Teeter, A., H. Benson, and C. Callegan. Draft report. Shoreline Conditions near Hobcaw Point, Wando River, Charleston Harbor, South Carolina. (For more information, contact the author, Brandan Scully, Brandan.M.Scully@usace.army.mil.)
} 
capacity required to transport projected cargo flows. Thus, it was determined that given the study projections for cargo growth and future vessel populations, shoreline impacts would likely be less in future scenarios where deepening was performed than in non-deepened scenarios.

ADDITIONAL INFORMATION: This Coastal and Hydraulics Engineering Technical Note (CHETN) was prepared as part of the USACE Coastal Inlets Research (CIRP) Program by Anne McCartney, formerly of the U.S. Army Engineer District, Charleston, SC (SAC), and Brandan Scully of the U.S. Army Engineer Research and Development Center, (CE-ERD). Additional information regarding the CIRP can be found at the CIRP website http://cirp.usace.army.mil.

Questions regarding this CHETN may be addressed to the following:

Brandan Scully Brandan.M.Scully@usace.army.mil

(CE-ERD Point of Contact)

Mary Cialone Mary.A.Cialone@usace.army.mil

(USACE CIRP Acting Program Manager)

This ERDC/CHL CHETN-IX-46 should be cited as follows:

Scully, Brandan M., and Anne C. McCartney. 2017. Use of AIS and AISAP for Analysis of Vessel Wakes in Charleston Harbor: A Case Study. ERDC/CHL CHETN-IX-46. Vicksburg, MS: U.S. Army Engineer Research and Development Center. http://dx.doi.org/10.21079/11681/22908

\section{REFERENCES}

International Telecommunication Union (ITU). 2014. Technical Characteristics for an Automatic Identification System Using Time-Division Multiple Access in the VHF Maritime Mobile Band. Recommendation ITU-R M.1371-5.

Kriebel, D. L., and W. N. Seelig. 2005. “An Empirical Model for Ship-Generated Waves.” In Proc., 5th Int. Symp. on Ocean Wave Measurement and Analysis (CD-ROM), Madrid, Spain.

Maynord, S. T. 2007. Ship Forces on the Shoreline of the Savannah Harbor Project. ERDC/CHL TR-07-7. Vicksburg, MS: U.S. Army Research and Development Center. https://erdc-library.erdc.dren.mil/xmlui/handle/11681/7703.

Maynord, S. T., D. S. Biedenharn, C. J. Fischenich, and J. E. Zufelt. 2008. Boat-Wave-Induced Bank Erosion on the Kenai River, Alaska. ERDC TR-08-5. Vicksburg, MS: U.S. Army Engineer Research and Development Center. https:/lerdc-library.erdc.dren.mil/xmlui/handle/11681/8579.

Permanent International Association of Navigation Congresses (PIANC). 2002. Guidelines for the Design of Fender Systems. "Report of Working Group 33 of the Maritime Navigation Commission." MarCom Report, Volume 33.

Stolker, C., and H. J. Verheij. 2006. “Ship-Induced Water Motions beneath the Ship's Hull." In 31st PIANC International Navigation Congress, May 14-18, 2006, Estoril, Portugal,467-472.

U.S. Army Corps of Engineers (USACE). 2005. Part 1-Waterways and Harbors Atlantic Coast. IWR-WCUS-11-1. Washington, DC: U.S. Army Corps of Engineers. http://www.navigationdatacenter.us/wcsc/pdf/wcusatlo5.pdf.

USACE. 2008. Coastal Engineering Manual. EM 1110-2-1100. Washington, DC: U.S. Army Corps of Engineers. http://www.a-jacks.com/Coastal/GeneralInfo/CEM/CEM.aspx. 
USACE. 2011. Part 1-Waterways and Harbors Atlantic Coast. IWR-WCUS-11-1. Washington, DC: U.S. Army Corps of Engineers. http://www.navigationdatacenter.us/wcsc/pdf/wcusatl11.pdf.

USACE, Charleston District. 2015. Charleston Harbor Post 45 Final Integrated Feasibility Report and Environmental Impact Statement. U.S. Army Corps of Engineers, Charleston District. http://www.sac.usace.army.mil/Portals/43/docs/civilworks/post45/finalreport/1_Main\%20Report\%20and\%20EI S.pdf.

Winkler, D. 2012. Presentation: AIS Data Quality and the Authoritative Vessel Identification Service (AVIS). U.S. Coast Guard Operations Systems Command. https://www.navcen.uscg.gov/pdf/AIS/FAQ/16/ Winkler@GMDSS_TF_\%282012-01-11\%29_AIS_Data_Quality.pdf.

NOTE: The contents of this technical note are not to be used for advertising, publication,

or promotional purposes. Citation of trade names does not constitute an official endorsement or approval of the use of such products. 